\title{
UMOWY CYWILNOPRAWNE A SPECYFIKA ZAWODU NAUCZYCIELA
}

\begin{abstract}
Streszczenie. Przedmiotem artykułu jest dopuszczalność stosowania umów cywilnoprawnych do zatrudniania nauczycieli w kontekście specyfiki tej grupy zawodowej. Zmiana w przepisach dotyczących zakazu zatrudniania nauczycieli na podstawie tych umów skłania do refleksji i skomentowania jej zasadności. Autorka charakteryzuje korzyści, jakie płyną dla nauczycieli szkół niepublicznych w związku z tą modyfikacją, oraz straty, jakie mogą ponieść pracodawcy. Omawiana zmiana weszła w życie 1 września 2018 r. i jest różnie oceniana przez dyrektorów szkół niepublicznych, jak i przez samych nauczycieli. W końcowej części artykułu autorka formułuje własną opinię na ten temat.
\end{abstract}

Slowa kluczowe: umowy cywilnoprawne, specyfika zawodu nauczyciela, prawo pracy.

Chociaż prawo pracy wywodzi się z prawa cywilnego, to obecnie jest samodzielną dziedziną prawa. „Podstawowa konstrukcja prawna prawa pracy, jaką jest stosunek pracy, to przekształcony stosunek cywilnoprawny najmu pracy, podobnie umowa o pracę jest odmianą ogólnosystemowej konstrukcji umowy, najpełniej poddaną regulacji w prawie cywilnym. Związki prawa pracy z prawem cywilnym są zatem naturalne" (Stelina 2016, 23). Wzajemną relację tych gałęzi określa art. 300 Kodeksu pracy (Ustawa z 26 czerwca 1974 r., tekst jedn.: Dz.U. z 2018 r., poz. 917) (dalej: k.p.). Zgodnie z tym przepisem, w sprawach nieunormowanych przepisami prawa pracy do stosunku pracy stosuje się odpowiednio przepisy Kodeksu cywilnego, jeżeli nie są one sprzeczne z zasadami prawa pracy. Odpowiednie stosowanie przepisów Kodeksu cywilnego oznacza, że niektóre przepisy stosujemy wprost, inne po modyfikacji, a jeszcze inne nie mają zastosowania. W przypadku kwestii w ogóle nieuregulowanych przepisami Kodeksu pracy, takich jak choćby wykładnia oświadczeń woli, zastosowanie przepisów prawa cywilnego jest konieczne i bezsprzeczne. Jeżeli natomiast mamy do czynienia ze sprawami unormowanymi w jakiś sposób w prawie pracy, chociażby częściowo, pojawia się wątpliwość, czy możliwe jest w takiej sytuacji uzupełniające stosowanie regulacji Kodeksu cywilnego. Jeżeli umowa cywilnoprawna z wykonawcą pracy zawiera wszystkie cechy stosunku pracy, to wówczas mamy do czynienia $\mathrm{z}$ wykroczeniem przeciwko prawom pracownika, które zostało uregulowane

* Uniwersytet Łódzki, Wydział Prawa i Administracji, Katedra Prawa Pracy, ewelina_szadkowska@wp.pl 
w dziale trzynastym Kodeksu pracy Zgodnie z art. 281 cytowanego aktu, kto, będąc pracodawcą lub działając w jego imieniu, zawiera umowę cywilnoprawną $\mathrm{w}$ warunkach, w których zgodnie z art. 22 § 1 k.p. powinna być zawarta umowa o pracę - podlega karze grzywny od 1000 zł do 30000 zł. Taką umowę można również zakwestionować przed sądem pracy. Częstym zjawiskiem jest zatrudnianie wykonawców na podstawie umów cywilnoprawnych w celu zredukowania kosztów osobowych. Są to przede wszystkim składki na ubezpieczenia społeczne, ale także inne obciążenia związane z zatrudnieniem pracowniczym, np.: wynagrodzenie za urlop wypoczynkowy, za czas niezdolności do pracy związanej z chorobą czy za okres przestoju, jak również inne płatne zwolnienia od świadczenia pracy (urlopy okolicznościowe), w tym dotyczące macierzyństwa.

Dotychczas nauczyciele placówek publicznych, co do zasady, zatrudniani byli na podstawie umów o pracę, zgodnie z przepisami Karty Nauczyciela (Ustawa z 26 stycznia 1982 r., Dz.U. z 2018 r., poz. 967) (dalej: KN). W myśl art. 10 ust. 1 tego aktu, stosunek pracy z nauczycielem nawiązuje się w szkole, a w przypadku powołania zespołu szkół jako odrębnej jednostki organizacyjnej - w zespole szkół, na podstawie umowy o pracę lub mianowania. Natomiast dyrektorzy szkół oraz przedszkoli niepublicznych angażowali nauczycieli w dwojaki sposób: w ramach umowy o pracę oraz na podstawie umów cywilnoprawnych. Pozwalała na to regulacja prawna, bowiem nie było w tej materii żadnych ograniczeń. Stanowisko judykatury było tu jednoznacznie ukierunkowane na możliwość zawierania umów cywilnoprawnych z nauczycielami szkół niepublicznych. Sąd Najwyższy w wyroku z dnia 18 lipca 2012 r. (sygn. akt I UK 90/12) uznał, że jak najbardziej dopuszczalne jest zatrudnianie nauczycieli na podstawie umów cywilnoprawnych w szkołach niepublicznych o uprawnieniach szkół publicznych. Sąd Najwyższy w cytowanym orzeczeniu stwierdził, że dopuszczalne jest, aby nauczyciele w tej samej placówce byli zatrudniani zarówno na podstawie umów cywilnoprawnych, jak i umów o pracę. Nie miało znaczenia, że i jedni, i drudzy wykonywali tę samą pracę, w identyczny sposób byli podporządkowani, wykonywali zadania zlecone przez dyrektora szkoły i brali udział w imprezach szkolnych, dyżurach na przerwach oraz w zebraniach z rodzicami i radach pedagogicznych. Moim zdaniem, wyrok ten naruszał zasadę równego traktowania oraz był sprzeczny z przepisami k.p. Zgodnie z bezwzględnie obowiązującym art. $22 \S 1^{1}$ tego aktu, zatrudnienie w warunkach charakterystycznych dla stosunku pracy, kiedy praca wykonywana jest osobiście, na rzecz pracodawcy i jego ryzyko, pod kierownictwem podmiotu zatrudniającego, w miejscu i czasie przez niego wyznaczonym, jest zatrudnieniem na podstawie stosunku pracy, bez względu na nazwę zawartej przez strony umowy. Nie jest także dopuszczalne zastąpienie umowy o pracę umową cywilnoprawną przy zachowaniu dotychczasowych warunków wykonywania pracy (art. 22 $\S 1^{2}$ k.p.). O ile w tym stanie faktycznym nauczyciele zatrudniani na podstawie umów cywilnoprawnych byli na emeryturach bądź posiadali zatrudnienie w innej placówce, tak w przypadku osób, które nie miałyby innych możliwości, było 
to wysoce niesprawiedliwe i często zależało od osobistych sympatii dyrektora. Sąd Najwyższy w analizowanym wyroku powołał się na uchwałę z 20 września 1994 r. (I PZP 37/94, OSNP 1995, nr 7, poz. 86), z której wynika, że do nauczycieli szkół niepublicznych o uprawnieniach szkół publicznych nie stosuje się wyżej cytowanego art. $10 \mathrm{KN}$. Podobne stanowisko zajął SN w wyroku z 30 maja $2001 \mathrm{r}$. (I PKN, OSNP 2003, nr 7, poz. 174), wskazując, że zatrudnianie nauczycieli w niepublicznej szkole artystycznej również nie jest realizowane na podstawie KN. Sąd Najwyższy wielokrotnie podkreślał, że zgodna wola stron przesądza o fakcie, w jaki sposób może być zawarta umowa z wykonawcą pracy, nawet jeżeli inne regulacje są dla niego korzystniejsze (zob. np.: wyrok SN z 24 listopada 2011 r., I PK 62/11, Lex nr 1109362; wyrok SN z 6 kwietnia 2011 r., II UK 315/10).

Z kolei w wyroku z dnia 27 maja 2010 r. (II PK 354/09, Lex nr 598002) SN stwierdził, że w razie ustalenia, iż zawarta umowa wykazuje wspólne cechy dla umowy o pracę i umowy cywilnoprawnej z jednakowym ich nasileniem, to o ich typie rozstrzyga wola stron. W związku z brakiem regulacji prawnej w tym zakresie, do tej pory do nauczycieli placówek niepublicznych miały zatem zastosowanie ogólne zasady zatrudnienia. „Swoboda wyboru podstaw i ram prawnych zatrudnienia wynika z wolności podejmowania przez osoby i podmioty decydujące się na nawiązanie stosunku prawnego, w ramach którego wykonywana będzie praca zarobkowa, działań zmierzających do swoistej transakcji handlowej, polegającej na wymianie umiejętności fachowych oraz udostępnieniu własnego czasu wolnego innej osobie lub podmiotowi występującemu w stosunkach społecznych regulowanych przepisami prawa pracy w charakterze potencjalnego pracodawcy zainteresowanego w wykorzystaniu dla własnych celów umiejętności i czasu osoby kandydata do pracy" (Świątkowski 2015, 57).

Ograniczenia dotyczące możliwości stosowania do nauczycieli umów prawa cywilnego zostały wprowadzone ustawą o finansowaniu zadań oświatowych Ministerstwa Edukacji Narodowej z 27 października 2017 r. (Dz.U. z 2017 r., poz. 2203). W związku ze zmianami w ustawie o finansowaniu zadań oświatowych MEN, od 1 września 2018 roku obowiązuje art. 10a KN. Zgodnie z założeniami zawartymi w ww. ustawie, w publicznych innych formach wychowania przedszkolnego, przedszkolach, szkołach i placówkach prowadzonych przez osoby fizyczne oraz osoby prawne niebędące jednostkami samorządu terytorialnego oraz w niepublicznych innych formach wychowania przedszkolnego, przedszkolach i placówkach oraz szkołach niepublicznych o uprawnieniach szkół publicznych - nauczyciele mogą być zatrudniani jedynie na podstawie umowy o pracę na zasadach określonych w Kodeksie pracy. Celem tej regulacji jest zapewnienie odpowiedniego poziomu procesu nauczania, jak również konieczność zagwarantowania nauczycielom podstawowych uprawnień pracowniczych. Zawieranie umowy o pracę wiąże się z zapewnieniem warunków pracy określonych w umowie o pracę, te natomiast nie mogą być mniej korzystne niż przepisy prawa pracy. Ważnym przywilejem wynikającym z Kodeksu pracy jest prawo do płatnego 
urlopu wypoczynkowego. Zawieranie umów cywilnoprawnych pozbawia bowiem nauczyciela prawa do wypoczynku, a wszystkie okresy, w czasie których nie świadczy pracy, są bezpłatne. Ma to spore znaczenie w przypadku szkół, które w okresie wakacji nie pracują. Dochodzi tutaj do sytuacji dłuższej przerwy w zatrudnieniu, która nie jest korzystna dla nauczycieli. Kolejnym uprawnieniem, które zapewnia Kodeks pracy, jest zakaz dyskryminacji; poczucie sprawiedliwości ma pewien wpływ na zaangażowanie w pracę, a co za tym idzie, jakość świadczonej pracy. Ponadto pracodawca zatrudniający nauczyciela na podstawie umowy o pracę musi zapewnić mu odpowiednią wysokość wynagrodzenia zagwarantowaną rozporządzeniem Ministra Edukacji Narodowej w całym okresie zatrudnienia, tak aby odpowiadało ono kwalifikacjom i rodzajowi wykonywanej pracy.

Następnie warto wspomnieć o ochronie trwałości zatrudnienia, jaka występuje jedynie w ramach stosunku pracy. Zwolnienie pracownika nie może zasadniczo nastąpić ,z dnia na dzień”, a w przypadku nauczycieli, zgodnie z KN, okres wypowiedzenia umowy o pracę wynosi 3 miesiące i możliwe jest jego dokonanie tylko w taki sposób, aby stosunek pracy został rozwiązany z końcem roku szkolnego oraz muszą wystąpić konkretne okoliczności. W myśl art. 20 ust. $1 \mathrm{KN}$, dyrektor szkoły w razie: 1) całkowitej likwidacji szkoły rozwiązuje z nauczycielem stosunek pracy; 2) częściowej likwidacji szkoły albo w razie zmian organizacyjnych powodujących zmniejszenie liczby oddziałów w szkole lub zmian planu nauczania uniemożliwiających dalsze zatrudnianie nauczyciela $\mathrm{w}$ pełnym wymiarze zajęć rozwiązuje z nim stosunek pracy lub, na wniosek nauczyciela, przenosi go w stan nieczynny. Rozwiązanie stosunku pracy z przyczyn określonych powyżej następuje z końcem roku szkolnego po uprzednim trzymiesięcznym wypowiedzeniu (art. 20 ust. $3 \mathrm{KN}$ ). Kolejną istotną kwestią, na jaką należy zwrócić uwagę, jest szczególna ochrona trwałości stosunku pracy. W przypadku umów cywilnoprawnych nie występuje ochrona kobiet w ciąży, w ramach której pracodawca nie może wypowiedzieć ani rozwiązać umowy o pracę w okresie ciąży, a także w okresie urlopu macierzyńskiego pracownicy, chyba że zachodzą przyczyny uzasadniające rozwiązanie umowy bez wypowiedzenia z jej winy i reprezentująca pracownicę zakładowa organizacja związkowa wyraziła zgodę na rozwiązanie umowy (art. $177 \S 1$ k.p.). Ochrona ta w prawie pracy rozciąga się również na okres korzystania przez pracownika z urlopu macierzyńskiego, rodzicielskiego i wychowawczego.

Przeciwnicy wprowadzonych zmian podają argument, że zatrudniają nauczycieli na podstawie umów cywilnoprawnych jedną godzinę w tygodniu. Wymiar czasu pracy dla nauczycieli nie powinien budzić wątpliwości. Kodeks pracy nie określa minimalnego wymiaru czasu pracy, w związku z powyższym argument ten jest bezzasadny. Bardziej kłopotliwe niż sporządzenie umowy cywilnoprawnej jest zatrudnienie pracownika na wyjątkowo małą część etatu, jest to jednak możliwe. Oczywiste konsekwencje finansowe analizowanej zmiany ponosi pracodawca; poza obowiązkowym odprowadzaniem składek na ubezpieczenie społeczne, 
wymagane jest stworzenie pełnej pracowniczej dokumentacji. Nie jest natomiast kłopotliwe rozłożenie czasu pracy tak, żeby nauczyciel wykonywał ją w określonym czasie.

Możliwe jest zatrudnianie nauczycieli, którzy świadczą pracę tylko przez jeden semestr na podstawie umowy o pracę na czas określony (bez limitu ilościowego i czasowego). Co prawda Kodeks pracy w art. $25^{1}$ określa liczbę oraz maksymalny czas trwania umów o pracę na czas określony, jednakże w $\S 4$ tego artykułu ustawodawca stanowi, że przepisu tego nie stosuje się do umów o pracę zawartych na czas określony w przypadku, gdy pracodawca wskaże obiektywne przyczyny leżące po jego stronie - jeżeli ich zawarcie w danym przypadku służy zaspokojeniu rzeczywistego okresowego zapotrzebowania i jest niezbędne w tym zakresie w świetle wszystkich okoliczności zawarcia umowy. Regulacja ta w oczywisty sposób będzie miała zastosowanie do nauczycieli.

Jedną z zalet analizowanej tu nowelizacji jest to, że nauczyciele publicznych form wychowania przedszkolnego, prowadzonych przez osoby prawne niebędące jednostkami samorządu terytorialnego lub osoby fizyczne, oraz niepublicznych innych form wychowania przedszkolnego zostaną objęci przepisami KN w takim samym zakresie jak nauczyciele niepublicznych przedszkoli. Oznacza to, że specjaliści od nauczania będą mieli możliwość uczestniczenia w procesie awansu zawodowego. Jest to o tyle istotne, że nauczyciele zmieniając miejsce świadczenia pracy, chociażby z placówki niepublicznej na publiczną, nie będą mieli poczucia straconego czasu w kwestii podwyższania swoich kwalifikacji. Zdobywanie kolejnych stopni awansu zawodowego wpływa również na wysokość wynagrodzenia. Rozporządzenie Ministra Edukacji Narodowej z 26 marca 2018 r. zmieniające rozporządzenie w sprawie wysokości minimalnych stawek wynagrodzenia zasadniczego nauczycieli, ogólnych warunków przyznawania dodatków do wynagrodzenia zasadniczego oraz wynagradzania za pracę w dniu wolnym od pracy (Dz.U. z 2018 r., poz. 638) reguluje wysokość minimalnych stawek wynagrodzenia zasadniczego nauczycieli obowiązujących od dnia 1 kwietnia 2018 r. Zgodnie z tymi przepisami, różnica między wynagrodzeniem nauczyciela stażysty a nauczyciela kontraktowego wynosi zaledwie 70 zł płacy zasadniczej brutto, a pomiędzy nauczycielem stażystą a nauczycielem mianowanym już 407 zł, natomiast między nauczycielem stażystą a nauczycielem dyplomowanym aż 900 zł. W związku z powyższym nauczyciel przechodzący z placówki prywatnej do publicznej nie zacznie od stopnia awansu zawodowego nauczyciela stażysty, tylko od takiego stopnia, jaki sam sobie wypracuje przez lata pracy, bez względu na upublicznienie placówki.

Nieodłącznym warunkiem zdobywania kolejnych stopni awansu zawodowego jest pogłębianie wiedzy i umiejętności zawodowych, samodzielnie lub przez udział w różnych formach kształcenia ustawicznego. Nowa regulacja pozwala także nauczycielom placówek niepublicznych korzystać z form doskonalenia ze środków wyodrębnionych w budżecie wojewody i w budżecie Ministra Edukacji 
Narodowej. W związku z postępem technicznym, zmienia się również sam proces nauczania. Do szkół wprowadzane są nowe metody i sprzęt, które wymagają niejednokrotnie dodatkowego przeszkolenia. Zmieniają się także uczniowie, ich preferencje i predyspozycje. Możliwość korzystania z finansowanych form doskonalenia umożliwi wszystkim nauczycielom podnoszenie swoich kwalifikacji oraz umiejętności zawodowych, co należy ocenić pozytywnie. Ponadto nauczyciele placówek niepublicznych będą mieli możliwość uzyskania nagrody Kuratora, nagrody Ministra oraz Medalu Komisji Edukacji Narodowej. Dotychczas przywilej ten dotyczył tylko nauczycieli zatrudnionych na podstawie Karty Nauczyciela.

Pomimo nieodpartego wrażenia, iż zbiór przywilejów, jakie gwarantuje Karta Nauczyciela, jest zdecydowanie przesadzony, zatrudnianie nauczycieli na podstawie umów cywilnoprawnych jest moim zdaniem niewskazane. Charakter pracy nauczyciela nie współgra z zawieraniem takich umów, gdyż mogą one wpływać negatywnie na jakość procesu nauczania. Specyfika zawodu nauczyciela wiąże się z pracowniczym podporządkowaniem wobec dyrektora szkoły oraz z wykonywaniem bieżących poleceń przełożonego. Poza wcześniej wspomnianymi uprawnieniami dla nauczycieli, jakie niesie ze sobą zatrudnienie na podstawie umowy o pracę, istnieje jeszcze kwestia konieczności samodzielnego wykonywania pracy. W przypadku umowy zlecenia (umowy o dzieło), zleceniobiorca (przyjmujący zamówienie) może zlecić wykonanie zlecenia (dzieła) innym podmiotom, natomiast charakter pracy nauczyciela bezwzględnie wyklucza taką możliwość. Czym innym jest wyznaczenie przez dyrektora szkoły innej osoby w celu zastępstwa nieobecnego pracownika, a inaczej wygląda kwestia zlecenia wykonania pracy przez samego nauczyciela-zleceniobiorcę, w przypadku umów cywilnoprawnych.

Kolejnym istotnym argumentem przemawiającym przeciwko zawieraniu umów cywilnoprawnych z nauczycielami jest brak zależności i podporządkowania. Trudno wyobrazić sobie nauczyciela, który nie naucza według wskazanych podstaw programowych, oraz sytuację, gdy nie ma możliwości skontrolowania sposobu, w jaki wykonuje on swoje obowiązki edukacyjne. Co prawda, istnieje możliwość zawarcia w umowie zlecenia wskazówek od zleceniodawcy, którymi zleceniobiorca jest związany, jednak może on odstąpić od wskazanego przez zleceniodawcę sposobu wykonania zlecenia, jeżeli według zleceniobiorcy zaszła potrzeba zmiany sposobu wykonania zlecenia, czyli nastąpiła zmiana okoliczności lub też pojawiły się nowe, które uzasadniają taką zmianę, lub jeżeli zleceniobiorca nie ma możliwości uzyskania zgody zleceniodawcy na zmianę sposobu wykonania zlecenia (art. 737 Kodeksu cywilnego, ustawa z 23 kwietnia 1964 r., tekst jedn.: Dz.U. z 2018 r., poz. 1025) (dalej k.c.). Taka możliwość jest jednak niedopuszczalna w procesie nauczania. Zgodnie bowiem $\mathrm{z}$ art. 33 ust. 1 ustawy $\mathrm{z}$ dnia 7 września 1991 r. o systemie oświaty z dnia 7 września 1991 r. (Dz.U. z 2017 r., poz. 2198 ze zm.), nauczyciele podlegają nadzorowi pedagogicznemu. Organem nadzoru pedagogicznego o charakterze wewnętrznym jest dyrektor szkoły lub placówki oświatowej. W przypadku braku zależności i podporządkowania taki 
nadzór nie jest możliwy bądź jest istotnie utrudniony. Cechą charakterystyczną stosunku pracy jest podporządkowanie i zależność od przełożonego, a charakter pracy nauczyciela tego właśnie wymaga.

Wszystkie wymienione wyżej argumenty przemawiają za tezą, iż jedyną dopuszczalną podstawą zatrudnienia nauczycieli, uwzględniającą specyfikę wykonywanego przez nich zawodu, jest stosunek pracy. Bezzasadne wydaje się zatem w takim przypadku korzystanie z umów cywilnoprawnych, które nie biorą pod uwagę szczególnego charakteru pracy wykonywanej przez tę grupę zawodową. Inne stanowisko w tej materii mają przedsiębiorcy występujący w roli podmiotu zatrudniającego nauczycieli. Ich zdaniem, umowy o dzieło są jak najbardziej wskazane, chociażby ze względu na odprowadzane składki na Zakład Ubezpieczeń Społecznych. Dyrektorzy placówek, którzy do tej pory zatrudniali nauczycieli na umowy cywilnoprawne, są zdania, że nie uda im się zatrudnić specjalisty na bardzo małą część etatu na podstawie umowę o pracę. Tłumaczą to tym, że w takiej sytuacji nie będą mogli zapłacić nauczycielowi takiej stawki wynagrodzenia, jakiej on oczekuje. Inni dyrektorzy, zwłaszcza przedszkoli niepublicznych, będą zmuszeni podnieść czesne, ponieważ wzrosną koszty wynagradzania nauczycieli, co może przełożyć się na niską rentowność ich placówek oświatowo-wychowawczych. Dyrektorzy szkół niepublicznych, które nie pobierają opłat za nauczanie, obawiają się natomiast konieczności zamknięcia szkoły w związku z brakiem środków na jej utrzymanie. Będzie to dla nich zbyt duże obciążenie finansowe.

Moim zdaniem, jedynymi dopuszczalnymi sytuacjami zawierania umów cywilnoprawnych w oświacie powinny być przypadki, w których nie są realizowane obowiązki związane z zajmowaniem stanowiska nauczyciela (art. 42 ust. 2 KN), bądź też winno to dotyczyć jedynie tych powinności, które nauczyciel mógłby wykonywać w czasie i miejscu, które sam ustali, i są to warunki niezwiązane z organizacją szkoły, a najlepiej jeszcze niemające nic wspólnego z podstawą programową. Wtedy w mojej ocenie występuje przesłanka do zawarcia z nauczycielem umowy cywilnoprawnej. Faktem jednak jest, że zatrudnienie nauczyciela w przedszkolu lub szkole wiąże się z określonym miejscem i czasem wykonywania obowiązków oraz podporządkowaniem w stosunku do przełożonego, a także z realizacją podstawy programowej określonej prawem obowiązującym. W związku z powyższym uważam, że do zawodu nauczyciela ,nie pasują” umowy cywilnoprawne, ponieważ mogłyby upośledzić faktyczne funkcjonowanie placówek oświatowych, obniżając poziom jakości kształcenia w Polsce. Zawód nauczyciela nie jest ani zawodem wolnym, ani artystycznym. Podlega on pewnemu schematowi, co ma generować odpowiednio wysoką jakość nauczania. Dlatego też zasadne jest, moim zdaniem, stworzenie wszystkim nauczycielom możliwości rozpoczęcia ścieżki awansu zawodowego, co obecnie gwarantuje im jedynie zatrudnienie pracownicze. Dzięki temu przed całym środowiskiem nauczycielskim otwierają się równe szanse i perspektywy w zakresie pogłębiania kompetencji, a także 
ma to mobilizujący wpływ na podnoszenie ich kwalifikacji zawodowych. Karta Nauczyciela oferuje nauczycielom zatrudnionym na podstawie stosunku pracy wyjątkowo dużo przywilejów i uprawnień, czego obecnie pozbawione są osoby wykonujące ten zawód w ramach cywilnoprawnych stosunków zatrudnienia. Brakuje, moim zdaniem, unormowań, które pozwalałyby na wypośrodkowanie tego stanu rzeczy.

\title{
BIBLIOGRAFIA
}

Stelina, Jakub. 2016. Prawo pracy. Warszawa: C.H. Beck. Świątkowski, Andrzej Marian. 2015. W System Prawa Pracy. Tom VII. Zatrudnienie niepracownicze. Red. Krzysztof W. Baran. 57-113. Warszawa: Wolters Kluwer Sp. z o.o.

\section{Ewelina Szadkowska}

\section{CIVIL LAW CONTRACTS AND THE PROFESSION OF A TEACHER}

\begin{abstract}
The subject matter of the article is the admissibility of concluding civil law contracts to employ teachers, considering the specific character of this occupational group. A change in the regulations regarding the ban on employing teachers under such contracts encourages reflection and some comments on its legitimacy. The author describes the benefits gained from this modification by teachers employed at non-public schools, as well as the losses potentially suffered by employers. The change in the law came into force on 1 September 2018 and is viewed differently by headteachers and regular teachers. In the final part of the article, the author presents her own opinion on this issue.
\end{abstract}

Keywords: civil law contracts, the specificity of the teaching profession, labour law. 